\title{
Využití ergonomických a racionalizačních metod za účelem zvýšení efektivity pracoviště
}

\author{
Ilona Kačerová ${ }^{1}$, Filip Rybnikár ${ }^{1}$, Pavel Vránek ${ }^{1}$, Martin Kába ${ }^{1}$ \\ ${ }_{1}$ Západočeská univerzita v Plzni, Fakulta strojní, Katedra průmyslového inženýrství a \\ managementu \\ Univerzitní 2732/8, 30614 Plzeň, Česká republika \\ ikacerov@kpv.zcu.cz \\ rybnikar@kpv.zcu.cz \\ vranek@kpv.zcu.cz \\ kaba@kpv.zcu.cz
}

Anotace: Článek se zabývá ergonomickými metodami pro hodnocení určitých faktorů fyzické zátěže pracovníků manuálního pracoviště. Výzkum byl detailně zaměřen na měření lokální svalové zátěže a hodnocení ergonomie pracovního místa. S ohledem na výsledky ergonomického auditu byly poté navrženy racionalizační opatření pro zmírnění únavy pracovníků a zvýšení efektivity posuzovaného pracoviště.

\section{1 Úvod}

Počátky ergonomie Ize nalézt již v raných fázích vývoje lidstva, nejednalo se však o pojetí ergonomie jako známe dnes, nýbrž o jednoduché uzpůsobování pracovních nástrojů potřebám jejich uživatele. Za první primitivní ergonomické operace Ize považovat úpravu lidských obydlí pro zvýšení jejich pohodlí. Největší progres proběhl $v$ meziválečném a válečném období 20 . století. Pohled na ergonomii se $v$ průběhu jejího vývoje velmi změnil, na přelomu 20. a 21. století dominoval především rozvoj pokročilých systémů automatického řízení, automatika a výpočetní technika, v dnešní době je však kladen důraz na pracovní rizika, bezpečnost práce, a především pracovní pohodu. [6]

$\checkmark$ dnešní době je na průmyslové podniky $v$ oblasti ergonomie kladen velký důraz. Zaměstnavatelé si pomalu začínají uvědomovat, že ergonomické programy mají ve významných zahraničních podnicích výrazný podíl nejenom na jejich konkurenceschopnosti a prosperitě, ale také na dlouhodobé stabilitě. Ergonomie je považována za prostředek, který vede ke zvyšování efektivnosti lidské práce. Odprostit se od mechanocentrického přistupu nutí podniky především legislativní omezení, které obvykle vychází z ergonomických zásad, ale také národní a mezinárodní standardy společností. Je třeba si uvědomit, že ergonomické programy přináší podniku nejenom zvýšení kvality výroby, ale zajištují také efektivitu jednotlivých provozů, snižení výrobních nákladů, snížení fluktuace zaměstnanců a také přispívají ke snižení nákladů na péči o zdraví pracovníků. [1]

Zajištění ergonomie $v$ podniku je jedním $z$ hlavních piliřru dobře fungující společnosti, a to především díky tomu, že udržuje zaměstnance $v$ dobrém 
zdravotním stavu. Při návrhu či uspořádání pracoviště je třeba si položit několik otázek, od těch nejjednodušších až po ty složitější. Jsou polohy pracovníka při vykonávání činnosti príijatelné? Jaké jsou dosahové zóny pracovníka $\mathrm{v}$ rámci pracovního procesu? Jakým způsobem manipuluje pracovník s břemeny? Využíá pracovník při výkonu práce nadbytečnou sílu? Kolik pohybů rukou pracovník během směny vykoná? Nejenom na tyto otázky je třeba si při navrhování pracoviště odpovědět a vše přizpůsobit především lidem, protože právě ti jsou srdcem společnosti. V České republice je ergonomie zakotvena $v$ legislativě a měla by být striktně dodržována. Pokud podnik nesplňuje požadavky státu, hrozí mu velmi vysoké pokuty.

Článek popisuje řešení ergonomie $v$ rámci projektu na optimalizaci výrobních pracovišt'. Projekt byl zpracován v průmyslovém podniku, kde probíhá výroba dílů do leteckého průmyslu. Hlavní činností operátorů $v$ této výrobě je manuální nanášení lepidla na díly pomocí lepicí pistole, díly jsou po slepení $k$ sobě a oschnutí u pracovního stolu přebroušeny ruční bruskou do výsledné podoby. Práce je vykonávána vstoje s občasným přecházením k pracovnímu stolu s manuální bruskou. Výška pracovního stolu je standardizována pro všechny pracovníky $(80 \mathrm{~cm})$. Norma se liší dle typu výrobku. Práce je vykonávána ve dvousměnném provozu $v 7,5$ hodinových směnách +30 minut přestávka na jídlo a odpočinek. Pracoviště je vyobrazeno na obrázku 2, který je v kapitole níže.

\section{Posouzení ergonomičnosti pracoviště}

Česká legislativa nařizuje podmínky ochrany zdraví při práci ve všech sledovaných faktorech práce. Článek je zaměřen na zátěž fyzickou, proto nejsou v potaz brány ostatní aspekty pracoviště (hluk, biologičtí činitelé, světlo apod.). Obecně Ize říci, že fyzická zátěž pracovníka Ize rozdělit do tří kategorii:

- celková fyzická zátěž a ruční manipulace s břemeny,

- pracovní poloha,

- $\quad$ lokální svalová zátěž. [3]

Jednou z využívaných metod pro hodnocení pracovních poloh je metoda RULA, která není v legislativě ČR zakotvena, je však velmi často používána v rámci ergonomických auditů především kvůli její jednoduchosti.

Metoda RULA vznikla již roku 1993 na univerzitě $v$ Nottinghamu. Je celosvětově známá a uznávána pro hodnocení ergonomických rizik při pracovním postoji a při manipulaci s břemeny. RULA se používá především pro hodnocení poškození horních končetin vznikajících $v$ souvislosti $s$ pracovní činností. $V$ rámci RULA hodnocení je hodnocena poloha horních končetin (paže, předloktím zápěstí), krk, trup a nohy. Každé části těla je prířazenou bodové hodnocení. Body následně projdou korekcí s ohledem na svalové a silové pưsobení a následně je vypočteno celkové skóre viz grafické vyobrazení níže. [2] 


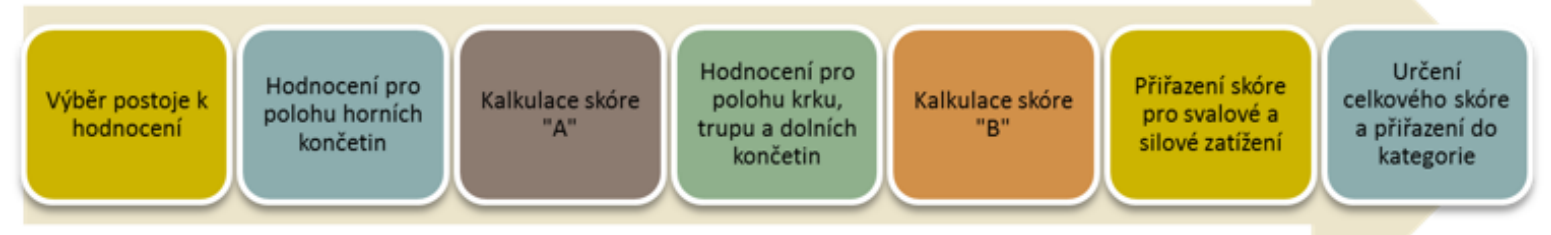

Obrázek 1 - Postup hodnocení pomocí metody RULA [2]

Celkové skóre je rozčleněno do 4 kategorií rizikovosti:

1. kategorie - práce príijatelná, není potřeba změn na pracovišti,

2. kategorie - práce je lehce riziková, je vhodné provedení určitých změn,

3. kategorie - práce riziková, je velmi žádoucí provést změny pro zlepšení pracoviště,

4. kategorie - extrémně riziková práce, jsou urgentní požadavky na změny pracoviště. [2]

Vzhledem k povaze genderového rozdělení pracovníků na pracovišti byl pro analýzu pomocí softwaru Tecnomatix Jack použit model člověka, který odpovídá prưměrné postavě dle německé databáze (žena, $162,5 \mathrm{~cm}, 66 \mathrm{~kg}$ ).

Nejprve byla metodou RULA zkoumána pozice pracovnice stojící u pracovního stolu a držícího lepicí pistoli, tato pozice byla ohodnocena 3 body, spadá tedy do 2 . kategorie, tato práce se dá označit za lehce rizikovou, je zde doporučeno provádět další změny pro racionalizaci pracoviště.

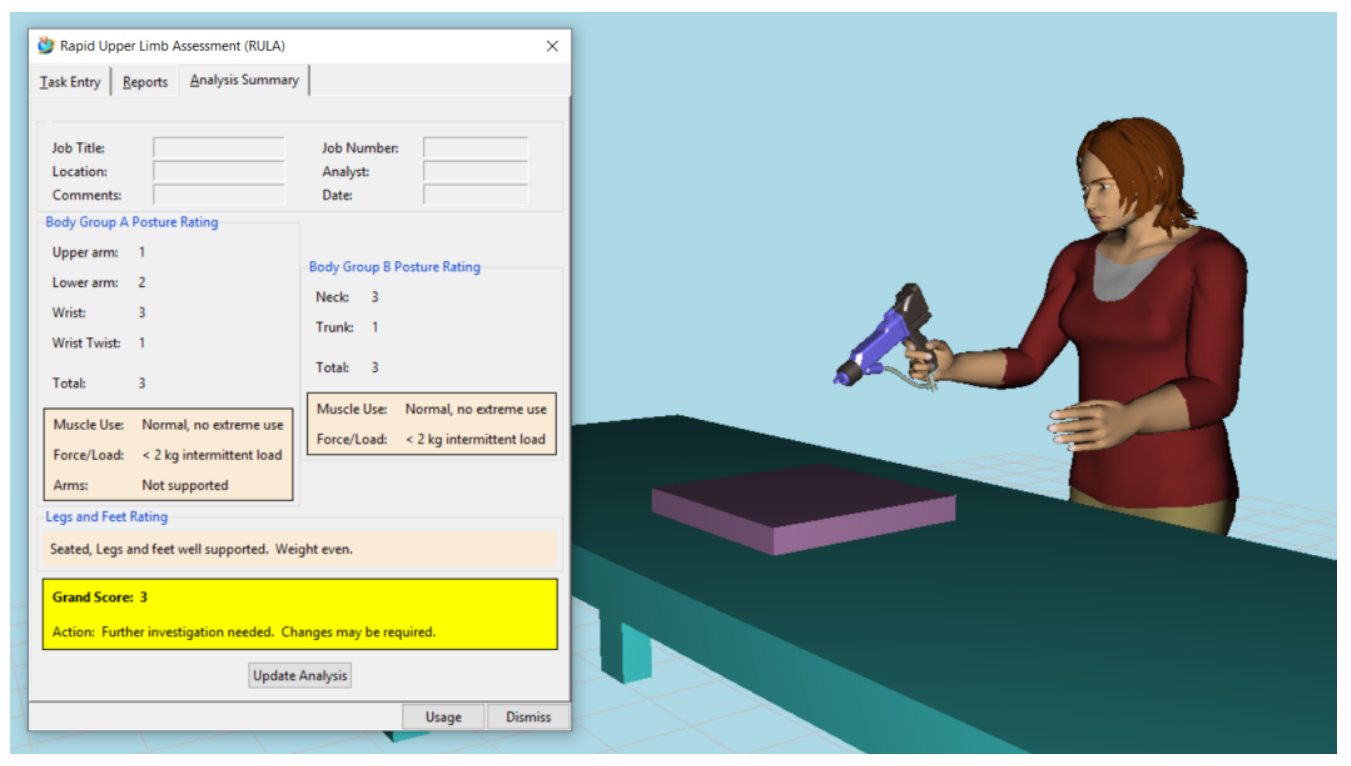

Obrázek 2 - Hodnocení pracoviště pomocí metody RULA 
Rozdělení prací do kategorií RULA analýzy není korespondující s rozdělením kategorií prací $v$ rámci kategorizace prací v České republice. Povinnost kategorizace prací je dána \$37, ze zákona č. 258/2006 Sb., o ochraně veřejného zdraví, vč. vyhlášky č. $432 / 2003$ Sb., které rozdělují práce na 4 kategorie podle stanovených pravidel. Toto rozdělení je základním prostředkem, který se podílí na hodnocení vlivu práce na zdraví zaměstnance. Jednotlivé kategorie jsou definovány mírou překročení hygienických limitů a rizikem ohrožení zdraví. $\vee$ rámci kategorizace fyzických faktorů jsou pracoviště děleny do tří pracovních kategorií:

1. Kategorie - není pravděpodobnost nepříznivého vlivu na zdraví pracovníků.

2. Kategorie - vliv na zdraví pracovníků je výjimečný, zejména u vnímavých jedinců. Hygienické limity nejsou překračovány.

3. Kategorie - hygienické limity jsou překračovány, je potřeba používat osobní ochranné pracovní pomůcky, statisticky je také častější výskyt nemoci z povolání. [7]

Z tohoto důvodu byla pracovní pozice analyzována dle NV č. 361/2007 Sb. Toto nařízení vlády stanovuje podmínky ochrany zdraví při práci. Legislativní nařízení rozděluje pracovní polohy dle jejich přijatelnosti na přijatelné, podmíněně príijatelné a nepřijatelné. Dále definuje průměrný hygienický limit pro dobu práce $v$ jednotlivých podmíněně príijatelných pracovních polohách $v$ průměrné 8 hod. směně na 160 minut. Průměrný hygienický limit pro polohy $v$ nepřijatelné poloze na 30 minut $v$ průměrné 8 hod. směně. [3]

V rámci pozorování pracovního postupu byl pořizen videozáznam pro detailnější zachycení pracovních úkonů a pracovních poloh. Videozáznam byl následně podroben detailnímu rozboru jednotlivých činností a pracovních poloh úhlů posuzovaných částí těla. $V$ prípadě pracovnice na pracovišti lepení byla práce přijatelná $S$ několika částmi $v$ podmíněně přijatelné poloze. Za problematickou oblast byla označena pravá horní končetina, a to od ramene až po zápěstí. Poloha lokte není specificky v rámci české legislativy prozatím definována. Problém nastal $v$ držení pistole, která není ergonomicky vhodná. $\checkmark$ podmíněně přijatelné poloze byl také krk. 


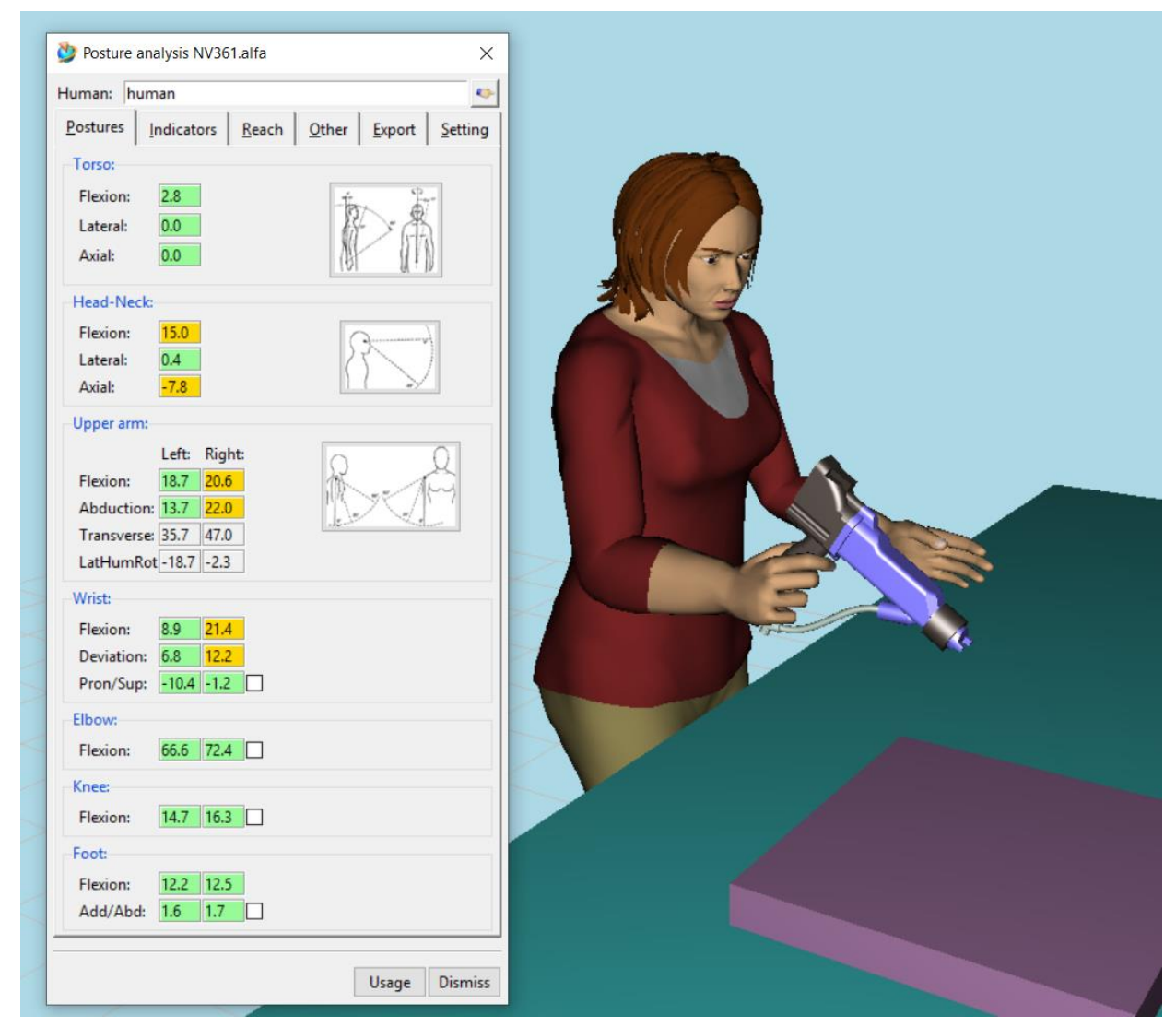

Obrázek 3 - Hodnocení pracoviště podle NV 361/2007 Sb.

Za nejproblematičtější oblasti byla označena pravá horní končetina pracovnice, která vzhledem $\mathrm{k}$ její poloze není vhodná a pracovníkům může zpưsobovat pracovní komplikace jako je např́iklad syndrom karpálního tunelu. Vzhledem $\mathrm{k}$ negativním indikacím analýzy RULA a z hodnocení pracovních poloh dle české legislativy bylo rozhodnuto, že pracoviště bude přeměřeno $z$ hlediska lokální svalové zátěže pomocí integrované elektromyografie.

Lokální svalová zátěž je zátěž malých svalových skupin při výkonu práce horními končetinami. $V$ rámci měření lokální svalové zátěže se zjištují a posuzují vynakládané svalové síly, počty pohybů a pracovní polohy $v$ závislosti na rozsahu statické a dynamické složky práce. Měření proběhlo pomocí integrované elektromyografie, pomocí prístroje EMG Holter, který je legislativou jediný uznávaný přístroj v České republice. [5]

Pracovní činnost byla přeměřena na dvou standardních pracovnicích.

Pracovnice 1:

- Věk: 40 let

- Výška: $167 \mathrm{~cm}$

- Váha: $62 \mathrm{~kg}$

- Dominantní horní končetina: levá,

- Maximální síla stisku: PHK 29,3 kg

- Maximální síla stisku: LHK 24,6 kg 
Pracovnice 2:

- Věk: 34 let

- Výška: $167 \mathrm{~cm}$

- Váha: $59 \mathrm{~kg}$

- Dominantní horní končetina: pravá

- Maximální síla stisku PHK: $23,7 \mathrm{~kg}$

- Maximální síla stisku LHK: $25,4 \mathrm{~kg}$

$\checkmark$ průběhu měření integrovanou elektromyografií dochází ke snímání elektrofyziologických biopotenciálů z vyšetřovaných svalových skupin ruky a předloktí - extensorů a flexorů. Výsledné údaje jsou následně zpracovány pomocí speciálního softwaru EMG Analyzer. Výsledkem měření jsou relativní hodnoty vynakládaných svalových sil v tzv. \% Fmax. [4] V rámci výzkumu byla provedena synchronizace výsledků EMG měření $s$ videem pracovního procesu, díky synchronizaci byly zjištěny úkony, při níž byly vykonávány nadlimitní síly (nad 70 \% Fmax, 55 - 70 \% Fmax).

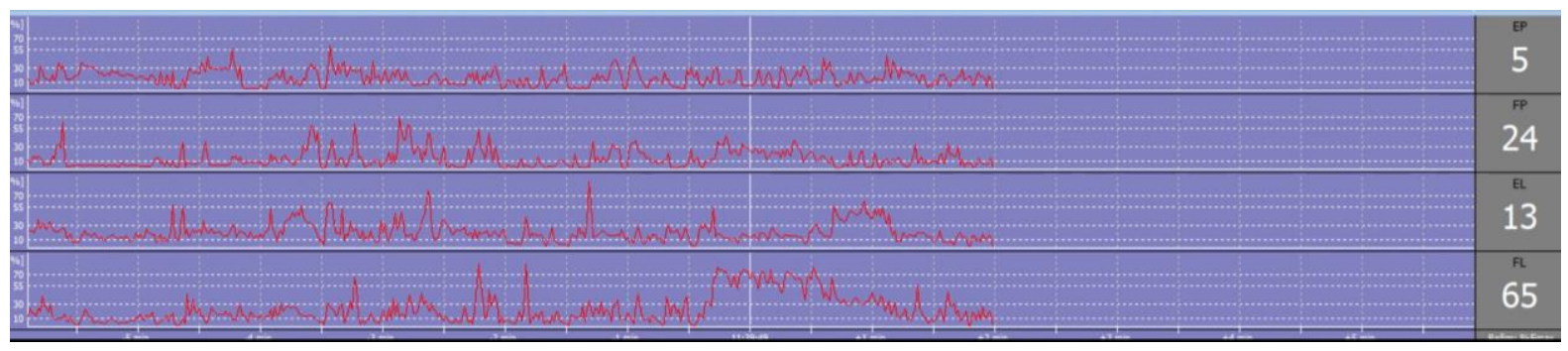

Obrázek 4 - Křivky EMG signálů - držení brusky

Vzhledem $k$ citlivosti údajů nelze výsledky měření zveřejnit. $Z$ měření však vyplynulo potvrzení dosavadních obav, poloha pravé končetiny byla označena za nepřijatelnou a bylo třeba vykonat urgentní nápravná opatření. Dalším ze zjištění bylo, že za problematickou oblast Ize z hlediska lokální svalové zátěže označit také broušení dílů, bruska byla značně těžká a pracovníci drželi horní končetinu $v$ nepríijatelné poloze po dlouhou dobu, čímž se zvýšil i výsledek EMG měření.

\section{Racionalizace výrobní linky}

$\checkmark$ rámci nápravných opatření bylo nutné pracovat $\mathrm{s}$ problematickým rozmístěním stolů, které musí kvưli instalaci odvětrávacího systému zůstat v dosavadním rozložení. Uspořádání stolů na lepení zůstalo stejné. $\mathrm{Na}$ pracovišti však vznikly 2 pracovní linky po každé straně. Linka pro složitější kusy a linka pro jednodušší kusy. Změnu pozice na pracovišti mělo pouze pracoviště broušení, které bylo přesunuto mezi pracovní linky. Dříve bylo až za rohem pracoviště lepení a pracovníci museli své slepené díly nosit velmi daleko. 


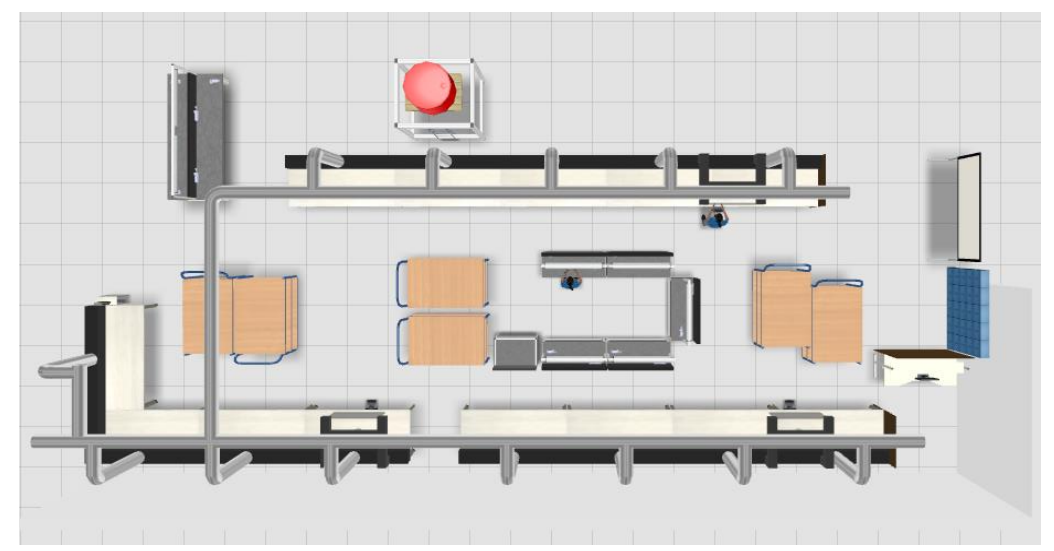

Obrázek 5 - Nové uspořádání linky

Nápravná opatření však neskončila u změny layoutu pracoviště. Zároveň se změnila technologie nanášení lepidla na pěnové díly. Vzhledem $k$ nepříznivým výsledkům EMG bylo v rámci návrhu této varianty pracováno se sprchou/tryskou nanášející lepidlo svrchu - vždy při stlačení nožního pedálu, čímž by se odbouralo držení lepicí pistole. Lepicí sprchy jsou schovány za plexisklo, aby lepidlo nestříkalo mimo. Pracoviště broušení bylo, jak již bylo zmíněno výše, umístěno mezi linky. Brusky byly zakomponovány do stolů jedna bruska horizontálně, druhá vertikálně a prípadně jedna bruska pro manuální broušení, kterému je ale třeba se $\mathrm{v}$ nejlepším případě úplně vyvarovat.

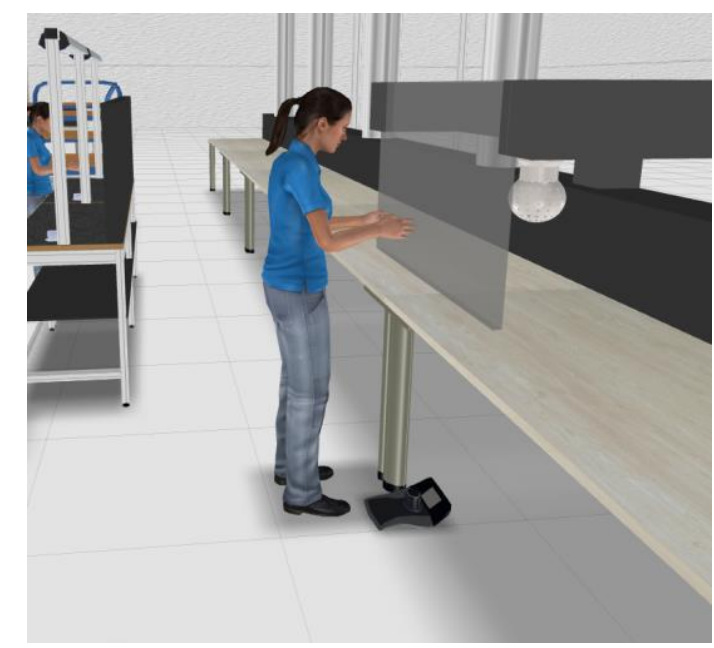

Obrázek 6 - Návrh nožního pedálu a nanášení lepidla pomocí trysky

\section{Závěr}

Ergonomie pracovního místa je dlouhodobě používaná a $v$ současné době inovována tak, že využívá kombinaci mnohých ergonomických nástrojů. Jejím hlavním prínosem je nalezení úspor pomocí snížení celkových nákladů na realizaci výroby, snížení výskytu nemocí z povolání a snížení fluktuace zaměstnanců. 


\section{Poděkování}

Tento článek byl vytvořen za podpory interního grantu Západočeské univerzity číslo projektu je SGS-2018-031 s názvem Optimalizace parametrů udržitelného výrobního systému.

\section{Použitá literatura}

[1] BUREŠ, M. Tvorba a optimalizace pracoviště. 1. vyd., SmartMotion s.r.o., PIzeň, 2013. ISBN 978-80-87539-32-3

[2] A step-by-Step Guide to the RULA Assessment Tool. In: ergo-plus.com [online]. [cit. 2018-04-04]. Dostupné z: http://ergo-plus.com/rulaassessment-tool-guide/

[3] Nařízení vlády č. 361/2007 Sb. In: zakonyprolidi.cz [online]. [cit. 2018-0305]. Dostupné z: https://www.zakonyprolidi.cz/cs/2007-361

[4] Elektromyografie (EMG) - Moje zdraví. Moje zdraví - péče o psychickou i fyzickou pohodu [online]. 2001 [cit. 5.7.2019]. Dostupné z: https://www.mojezdravi.cz/vysetreni/elektromyografie-emg-1922.html

[5] EMG Holter - Fyziologie práce. Uživatelský manuál [online]. 2018 [cit. 14.7.2019]. Dostupné z: http://fyziologie.getacentrum.cz/ke-stazeni/

[6] MAREK, J., SKŘEHOT, P. Základy aplikované ergonomie. VÚBP, v.v.i., Praha, 2009, 118 s. ISBN 978-80-86973-58-6.

[7] Kategorizace prací - BezpečnostPráce.info [online]. 2013 [cit. 04.12.2019]. Dostupné z: https://www.bezpecnostprace.info/dokumentace/kategorizacepraci/ 